\title{
Co-Offending Among Prison Inmates
}

\section{Lena Roxell'}

\begin{abstract}
The objective is to study the nature of co-offending among individuals who have previously spent time together in prison. Are new contacts established during a prison term that then result in co-offending subsequent to release? This question is examined on the basis of register data relating to all individuals released from Swedish prisons during a 6-month period $(n=3,930)$. The data show that $2 \%$ of the group were suspected of co-offending subsequent to having spent time together in prison. The findings are discussed on the basis of theoretical perspectives focusing on trust, contacts with other offenders, the size of the criminal networks involved, and criminal capital.
\end{abstract}

\section{Keywords}

prisons, inmates, co-offending, networks

\section{Introduction}

The research literature contains a number of descriptions of how time spent in prison can take form in relation to various prison cultures (see, for example, Bondeson, 1974; Clemmer, 1958; Goffman, 1961; Pollock, 2004; Sykes, 1958). Among other things, discussions have focused on the ways in which inmates interact with one another. We also know a good deal about what happens during the period subsequent to a term spent in prison, particularly as regard the relapse of former inmates into crime (Andersson, 1991, p. 72;

\footnotetext{
'Stockholm University, Stockholm, Sweden

\section{Corresponding Author:}

Lena Roxell, Department of Criminology, Stockholm University,

Universitetsvagen 10 C, Frescati, Stockholm 106 9I, Sweden

Email: Lena.Roxell@criminology.su.se
} 
BRÅ, 2007; Kriminalvårdsstyrelsen, 2005, p. 55-59; Kyvsgaard, 1989, p. 100). By contrast, we know relatively little about the links between these two phenomena, that is, whether contacts that are established in prison lead to subsequent co-offending. This article will therefore study whether prisons are places where contacts are established for the purposes of future criminality, which has been argued to constitute a problem in Sweden, both in the political debate and by the Prison and Probation Service (Justitiedepartementet Dir., 2002, p. 90; Kriminalvårdsstyrelsen, 2000, 2001). The article also studies whether such contacts result in co-offending relationships subsequent to inmates being released from prison.

The question of whether prisons function as schools of crime has long been a subject of debate and has been discussed from a variety of different perspectives. These discussions have moved from a focus on moral issues to seek explanations for the phenomenon in psychological or criminological theories (Gendreau, Goggin, \& Cullen, 1999; Hawkins, 1976). To take one example, the prison as a school of crime has been discussed in the context of explanations of recidivism. In this respect, the effect of time spent in prison is viewed in terms of interactions with other prison inmates resulting in individuals having a greater knowledge about the commission of crime subsequent to a prison term than they did before entering the prison environment. Co-offending with other former inmates subsequent to time spent in prison together may be viewed as an additional dimension of the school of crime phenomenon. Not only do inmates learn new techniques for committing offences but also do they find new people to commit offences with subsequent to their prison term.

Another effect of the prison sanction has been discussed in terms of the prisonization of inmates during their term in prison. Clemmer (1958) argues that inmates internalize attitudes and values that are drawn from prison cultures. The inmates adapt themselves to the conditions found in prisons and thus behave differently than they do when they are not incarcerated. Bondeson (1974, p. 521-527) finds that a process of prisonization occurs during inmates' time in prison institutions whereby inmates are exposed to negative influences, leading to both an increase in the intensity of criminal attitudes and socialization into a criminal subculture. The processes of positive influence, such as treatment and other forms of assistance provided during the prison term, are overshadowed by these negative influences. If inmates become prisonized during their time in prison, it is also conceivable that they become more interested in creating new contacts for the purposes of future criminality.

The objective of the current article is thus to study the nature of co-offending among people who have spent time together in prison. The term co-offending is 
used in this study to refer to individuals who are registered by the police as cosuspects in the commission of one or more offences.

\section{Previous Research on Co-Offending}

Explanations of why people choose to commit offences together with others have among other things been discussed in terms of benefits and risk. The benefits discussed include financial benefits, status, social intercourse (Weerman, 2003, p. 404), knowledge exchange (Felson, 2003), and a division of labor in connection with the offence itself (McCarthy, Hagan, \& Cohen, 1998) whereas the risks take the form of defections on the part of intended co-offenders or being informed on (McCarthy et al., 1998, p. 156; Weerman, 2003, p. 407). These explanations suggest that individuals conduct a risk-benefit analysis prior to deciding whether to commit offences together with others, that is, that the offence is preceded by rational choices. Research has also shown that co-offending assumes dynamic forms, in shifting constellations of co-offenders, for example. According to official register data on offending, it is uncommon for the same individuals to be suspected of committing offences together repeatedly (Reiss, 1988, p. 130; Reiss \& Farrington, 1991, p. 393; Sarnecki, 1986 , p. 57, 2001, p. 43). This would suggest that co-offending also occurs in more spontaneous forms and that the individuals involved are not necessarily always so calculating. It may, however, also be the case that those individuals who do commit offences together repeatedly know one another well, which might conceivably lead to them making fewer mistakes and thus not getting caught. This could then explain why repeat co-offending is uncommon in data based on registered criminality.

Previous research has shown that individuals usually commit offences both by themselves and together with co-offenders (Sarnecki, 1986, p. 57 \& 2001, p. 43; Reiss, 1988, p. 130; Reiss \& Farrington, 1991, p. 393). In other words, it is rare for individuals to commit offences exclusively by themselves, or exclusively together with co-offenders. Proportionally speaking, the level of offending with co-offenders decreases with age (Reiss \& Farrington, 1991, p. 384). One reason for this may be age-related changes in individuals' criminal careers (Kyvsgaard, 1998). Such changes may for example mean that individuals become less interested in committing offences with others, or that they shift to commit other types of crime which do not require the participation of more than one offender.

It has also been found that youths who co-offend commit offences together with individuals who are similar to them in terms of sex, age, residential neighborhood and degree of prior involvement in crime (Reiss \& Farrington, 
1991; Sarnecki, 1986, 2001, p. 65). The crime types involved are first and foremost minor offences when the offenders are youths. In a longitudinal study of males, who were aged 32 at the time for the observation, the findings showed however that individuals who engage in longer criminal careers commit offences with other males of different ages, from other residential areas and with varying levels of prior criminal experience (Reiss \& Farrington, 1991).

The types of crime found to be common in connection with co-offending vary somewhat between different studies. The age and sex of the study population, together with the crime classification employed, may all constitute explanations for these differences. On the basis of existing research, Weerman (2003, p. 399) found that drug offences, vandalism, burglary and robbery were common among offences where more than one offender was involved. Among youths, shoplifting and other theft offences have been found to be common in connection with co-offending (Sarnecki, 2001, p. 175), and among women the same is true of property offences (Koons-Witt \& Schram, 2003, p. 366).

The issue of the recruitment of co-offenders has been discussed on the basis of a network perspective (Reiss, 1988; Sarnecki, 1986, 2001). The point of departure here is that groups of individuals are linked to other groups, which facilitates recruitment between the different groups involved. This perspective could also provide us with insights into why people rarely commit offences with the same individuals repeatedly, since increased opportunities to come into contact with different individuals would also increase the opportunities to commit offences with several different individuals. Ianni (1975, cited in Tremblay, 1993, p. 24) showed that periods of imprisonment affected the form of networks of co-offenders to a greater extent in certain ethnic groups (Blacks and Puerto Ricans) than in others (Italians).

In Sweden, a number of studies have been conducted combining network analysis with register data on crime. Among other things, Sarnecki has studied youth crime in Borlänge, Stockholm, and Copenhagen (Sarnecki, 1986, 2001, 2002). In the Stockholm study, Sarnecki found, inter alia, that individuals who commit offences together with others are more often suspected of offences than those with no registered co-offenders. He also notes that it is uncommon for two individuals, or for larger groups, to be suspected of co-offending repeatedly (Sarnecki, 2001, p. 50). The structures found in youth offending networks are thus not fixed; instead the relationships vary in relation to both their duration and intensity. On the basis of interviews conducted with youths, Sarnecki (2001) has also noted that youth offending is spontaneous with regard to both when it is that offences are committed and whom the youths commit offences with (p. 164). Sarnecki $(1999,2001)$ has also studied youths admitted to special approved homes in Sweden on the basis of a network perspective. 
The results of his analysis indicate that time spent in these institutions has little significance for the establishment of new criminogenic relationships with individuals who have a history of involvement in crime.

In her doctoral dissertation, Pettersson (2002) examines supporter violence, ethnicity, and gender on the basis of a network analytical perspective. Roxell (2002) employs network analysis in a pilot study to examine the networks of gang members following a period spent in prison. Carlsson (2003) employs the method in the context of an evaluation of the work of the Robbery Squad in the Västerort district of Stockholm as a means of charting the nature of criminal networks. The Swedish National Council for Crime Prevention (BRÅ, 2005) has studied the networks of drug offenders by focusing on individuals convicted of aggravated drug offences and drug smuggling offences in the county of Stockholm in 2003. Among other things, these Swedish studies have shown that the networks examined change over time. It is rare for pairs of co-offenders to be registered as suspected of committing crimes together repeatedly. No findings are reported that might indicate that co-offending relationships are stable over time.

In summary, co-offending, perhaps unsurprisingly, has first and foremost been studied in the context of youth crime, and then, in particular, among males. Only a few studies have focused on girls and women (Koons-Witt \& Schram, 2003; Pettersson, 2002; Sarnecki, 2004) or on adults (Reiss \& Farrington, 1991). There is also a lack of explanations as to why certain types of crime, for example, are more common in the context of co-offending or which focus on the processes by which co-offenders are chosen. The existing research on co-offending has primarily been based on registered offending, which may be one reason why there is a lack of knowledge on certain aspects of the phenomenon. There is also a lack of research focusing on the question of whether time spent in prison has any effect on co-offending among inmates in general. As has been mentioned, however, a pilot study focusing on gang members has been conducted (Roxell, 2002) and research has been published on the co-offending of youths admitted to special approved homes (Sarnecki, 1999).

\section{Theoretical Points of Departure}

The theoretical framework for this work is intended to assist in producing knowledge about and facilitating the interpretation of the co-offending of individuals subsequent to a period spent in prison. That is to say, the intention is to clarify what may be of significance for whether individuals commit offences together subsequent to a joint period in prison. The point of departure employed here is a model which applies social exchange theory to the 
co-offending phenomenon (Weerman, 2003). Some form of social exchange takes place when people commit a crime together. The reason individuals commit offences together can be assumed to lie in benefits that cannot be obtained if individuals were to commit offences alone. Social exchange theory also contains a discussion of people's physical, economic, social, and psychological needs and desires (see, for example, Blau, 1964, 1994; Cook, 1990; Homans, 1958; Tribaut \& Kelley, 1959). The theory proceeds from the position not only that people strive to satisfy their needs and desires but also that they conduct cost and risk calculations. An exchange takes place when an individual believes that the benefit is greater than the costs and risks.

Weerman's (2003) model has three points of departure. First, the individual must be willing to engage in co-offending. Second, he or she must be accessible. Third, the person must appear attractive as a co-offender. In turn, these three points of departure are affected by a variety of factors, which the model specifies in terms of nine types. Four of these nine will be emphasized in the present context, namely trust, contacts with other offenders, the size of a criminal network, and criminal capital. These are also the most relevant factors on the basis of the available data.

The relationship between trust and offending has been discussed in terms of how people relate to risks and uncertainties (von Lampe \& Johansen, 2003, p. 3). Von Lampe and Johansen approach the issue from a variety of angles, of which three are relevant for the study presented here. The first of these is individual trust. This involves experiences of people's behaviors and character. The ways in which individuals have acted previously may be of significance for how they act in the future. In this context, prison is described as a place where continuous interactions make it possible to develop a view of how trustworthy individuals are (see also Nilsson, 2003). A third person may also function as a guarantor for another individual's trustworthiness. The second aspect is trust based on reputation. This can involve reputations within the criminal world and reputations gleaned from the media, for example. Individuals who care about their reputation are associated with a greater degree of trustworthiness. The third aspect relates to trust linked to various social groupings. If individuals are part of a group that is known to have certain norms or to engage in certain behaviors, this can become linked to an assessment of how much these individuals can be trusted. In summary, trust appears to be a function of both individual and social factors. In the register study, trust can be examined on the basis of whether the criminal relationships are stable. The assumption is then that stable networks in the form of lasting relationships require trust.

Contacts with people who have committed offences have been described by some scholars as a significant factor in relation to an individual's own criminality 
(see, for example, Sarnecki, 1986, 2001; Shaw \& McKay, 1942; Sutherland, 1939; Warr, 2002). Such contacts are also of significance for individuals' criminal careers, with people who commit many crimes more often committing offences with co-offenders than those who commit fewer crimes, for example (Reiss, 1988, p. 148). As was noted above, Sarnecki (2001, p. 42) has found that youths who commit offences together with others are registered more often for suspected offences than those with no registered co-offenders. This suggests that contacts with other individuals who engage in criminal activity increase the frequency of involvement in crime at the individual level. There are, however, scholars who have a completely different view of the significance of other people for individuals' involvement in crime (see, for example, Hirschi, 1969). Nilsson (2002, p. 146) found that persons who predominantly socialize with other offenders reoffend quicker subsequent to their prison term than persons who predominantly socialize with nonoffenders. In other words, there is previous research indicating that contacts with other offenders increase the frequency of both recidivism and of offending.

Prison may nonetheless be viewed as a special environment when it comes to contacts with other offenders. How are inmates affected by their constant interaction with other offenders under the special conditions that exist in prisons? How are they affected, for example, by the hierarchies found in prisons? As has already been noted, a study by Bondeson (1974, p. 521-527) found evidence of a process of prisonization, whereby inmates were negatively affected by their time in prison, developing more criminal attitudes as a result and becoming socialized into a criminal subculture. Such conditions would be expected to promote the development of the inmates' networks of contacts. This is underlined by Alnæs (2006, p. 150) who found that prison is a place where new contacts are established. Thus, periods spent in prison may be viewed as times which provide opportunities to create contacts and which do so in an environment whose structural characteristics promote such contacts. At the same time, prison time must be viewed as special as a result of the major psychological strains that inmates are commonly exposed to (Pollock, 2004). Under such conditions, they may be expected to act and behave differently than they do during periods when they are not in prison.

The size of a criminal network affects the opportunities available to come into contact with potential co-offenders. We already know that co-offending relationships are rarely stable (BRÅ, 2005; Carlsson, 2003; Pettersson, 2002; Reiss, 1988; Sarnecki, 1986, 2001). This means that there is an interest in finding new co-offenders. We also know that individuals who have a large number of co-offenders, that is, a large criminal network, are suspected of committing offences more often than those with no registered co-offenders (Sarnecki, 2001, 
p. 42). The size of the network may also explain why offences are usually committed with different individuals because a large network produces greater opportunities to come into contact with different people.

Given that criminal relations are unstable, periods spent in prison constitute an excellent opportunity to establish new contacts for the purposes of future criminality. If co-offending relationships do in fact last a relatively short time, it would be reasonable for old relationships to be replaced with new ones that are established in prison. One factor that would speak against this possibility, however, is the spontaneous nature of crime (Sarnecki, 2001, p. 163). For co-offending actually to take place subsequent to a joint stay in prison, we would expect this to presuppose a certain level of planning, that the inmates be released at approximately the same time, and/or that they are interested in maintaining contact with one another for various reasons.

One of the central concepts employed in Hagan and McCarthy's (1997) study of homeless youth in Canada is that of criminal capital. The concept relates to both knowledge about how crimes are committed and ways of legitimizing criminal activities (p. 138). Capital in the form of knowledge and values is developed on the basis of the contacts formed in the networks of which individuals are a part. Hagan and McCarthy argue among other things that involvement in criminal networks, and the consequent acquisition of criminal capital, is of significance for learning certain types of crime and that it can be equated with processes found in the context of a more conventional life, such as the significance of knowledge and contacts for finding a regular job.

In the context of the current study criminal capital may be viewed as being of significance for the ability to establish contacts in prison and thus indirectly for future criminality. If we proceed from a view that inmates become prisonized during their stay in prison, this means that criminal norms and values become an important focus. If this is the case, then criminal capital would constitute an asset for the purposes of establishing contacts with others. It is also conceivable that young people can acquire criminal capital during their time in prison through contacts with older individuals.

\section{Method}

Data have been collected from a number of different official registers for the purposes of the current study. The target population comprises all individuals released from Swedish prisons during the 6-month period between October 1, 2001 and March 31, 2002. In other words, it represents a census rather than a sample study. The study population comprised 3,930 men and women. ${ }^{1}$ Table 1 presents the sex and age distribution of the study population, together with the 
Table I. Distribution of Sex, Age, and Prison Type for the Survey Population

\begin{tabular}{lrr}
\hline & $n$ & Proportion \\
\hline Sex & 246 & 6 \\
Female & 3,684 & 94 \\
Male & & \\
Age & 779 & 20 \\
I8-25 & 1,161 & 29 \\
$26-35$ & 1,163 & 29 \\
$36-45$ & 622 & 16 \\
$46-55$ & 185 & 5 \\
$56-65$ & 20 & 1 \\
$66-77$ & & 3 \\
Prison type & 128 & 38 \\
Closed with high security/closed & 1,483 & 23 \\
Closed & 898 & 36 \\
Closed/open & 1,421 & \\
Open & & \\
\hline
\end{tabular}

Note: Proportions in percentage. $n=3,930$.

type of prison from which they were released. The prison type variable is based on the different institutions' security classification. Prisons could have different types of sections, both closed and open.

To address the question of co-offending subsequent to a period of imprisonment, data were collected from the Register of Suspected Offenders. These data were provided by the Swedish National Council for Crime Prevention and are based on all offences registered by the police that have been linked to one or more suspected offenders. The register also contains information on suspected co-offenders. ${ }^{2}$ At the time the data were provided, the register included information for the period between 1995 and July 1, 2004. This allows for a follow-up period of between 2 years, 3 months and 2 years, 9 months, depending on a given inmate's date of release from prison. Of the 3,930 individuals in the study population, 3,810 were found in the Register of Suspected Offenders. This represents a level of missing cases of $3 \%$.

One problem associated with the use of the Register of Suspected Offenders is the well-known fact that only a fraction of the offences actually committed come to the knowledge of the police. In other words, we do not know whether individuals have committed offences together without this having been detected and registered. We do know that the propensity to report crime varies, 
depending among other things on the seriousness of the offence in question, on whether the victim and offender know one another, and on whether there is an insurance claim involved (BRÅ, 2006; von Hofer, 2006, p. 185). Prioritizations made by the police also play a role in which offences are registered. Certain individuals, such as persons with an immigrant background, may also be at greater risk of finding their way into the police register as a result of discriminatory mechanisms within the justice system (Sarnecki, 2006). The results of the register study should therefore be interpreted in the light of the fact that it is registered crime and nothing else that is being measured.

A further problem associated with the study is that the data only include information on the last prison the inmates stayed in prior to their release. This means that they may also have spent time in additional prisons in the course of their term of imprisonment and may have established contacts with future co-offenders in these other institutions.

\section{Results \\ Co-Offending}

The central question addressed in this piece of research is thus that of whether the individuals in the study population are suspected of having committed offences together subsequent to a joint stay in prison. To answer this question, data from the Register of Suspected Offenders were studied on the basis of the following principles. The suspected offences that were examined were those that occurred during the individuals' prison term or subsequent to their release. ${ }^{3}$ At the same time, the suspect and co-offender had to have simultaneously been inmates in the same prison for at least 1 day. ${ }^{4}$ Of the study population as a whole, $73 \%$ have been registered as suspects in connection with new offences subsequent to their release from prison.

The results show that 70 of the 3,810 individuals in the study population, or $2 \%$, are suspected of having committed offences together with an individual who was a fellow inmate in the same prison as them for some period. The results also show that these 70 individuals appeared in 36 co-offending partnerships, which were suspected of a total of 48 offences. ${ }^{5}$ Of these 36 co-offending partnerships, three of them (i.e., six individuals) were also suspected of having committed offences together prior to their prison term. This means that for these individuals, it was not new relationships established in prison that led to them subsequently being suspected of co-offending. Whether this is true for the remaining 64 individuals is something that can 
only be assumed, as there are no available data that can provide a definitive answer to this question.

By comparison with results from an examination of other co-offending constellations, this finding indicates that it is uncommon for former inmates to be suspected of committing offences together subsequent to a joint stay in prison. ${ }^{6}$ This also corresponds with the pilot study conducted previously, which produced the same results (Roxell, 2002). Given that the pilot study focused on a single prison and that the data set was produced in a different way, it is interesting that the results are so similar. The findings also correspond with those reported by Sarnecki (1999) in relation to co-offending subsequent to release from a stay in a special approved home. Sarnecki also found that new co-offending relationships were unusual subsequent to a stay in special approved homes. The finding is also to be expected on the basis of other research published in this area. This research has proceeded from other points of departure, however, and has focused on different populations. The finding would not, by contrast, be expected on the basis of the research that has viewed prisons as schools of crime, if co-offending is regarded as constituting part of this phenomenon.

Despite the fact that relatively few individuals were suspected of committing offences together subsequent to a joint stay in prison, these individuals will be examined in more detail. Do these individuals differ in some respect from the study population as a whole? This part of the study thus focuses on the 64 individuals who were suspected of co-offending subsequent to a joint stay prison and who had not previously been suspected of committing offences together.

\section{Co-Offending Prior to and After the Stay in Prison}

To begin with, the analysis examines the mean number of co-offenders found among the 64 individuals who were suspected of committing offences with a person they had served time with in prison. To be able to relate the results to the stay in prison, the periods prior to and subsequent to the prison term were both examined. Prior to the current prison term, the 64 individuals had a mean of 1.28 co-offenders per year, with this figure increasing to 1.84 per year during the period following their release from prison. By comparison with the study population as a whole, where the corresponding figures are 0.64 and 0.68 , respectively, this represents a larger number of co-offenders both prior to and subsequent to the period spent in prison. Thus the results show that these 64 individuals have a larger network of co-offenders than the members of the study population as a whole. 
This finding may be interpreted as indicating that individuals who have a larger number of co-offenders in their networks are also interested in further widening this network to include more co-offenders during the time they spend in prison.

\section{Sex and Age Distribution}

The sex and age distribution was then examined. This showed that $8 \%$ of the 64 individuals are women and $92 \%$ men. The average age is 34 years. ${ }^{7}$ The results show that this distribution is largely the same as that found in the study population as a whole. This indicates that sex has no significance for whether individuals become suspected of committing offences together subsequent to the conclusion of a joint stay in prison. Given that the proportion of offenders who engage in co-offending decreases with age, this finding is somewhat unexpected (Reiss \& Farrington, 1991, p. 384). We would instead have expected to find a larger proportion of the younger members of the study population in this group.

\section{Offence Types}

The offence types that the 33 co-offending partnerships were suspected of committing together are presented in Table 2. The table relates to a total of 45 offences.

The results presented in the table show that theft offences constitute the most common crime type that the individuals in question were suspected of committing together. The next most common offence types were offences against the Smuggling and Drug Offences Acts, followed by robbery. By comparison with the results for the study population as a whole, it is interesting to note that both drug offences and robbery are more common within the group examined here. Previous research has shown that robbery and also burglary are common offence types in the context of co-offending (Reiss \& Farrington, 1991, p. 373). At the same time, it should be noted that the number of offences examined here is small, which means that comparisons of percentages show large differences. It is also conceivable that certain offences types may be overrepresented during the specific period examined here.

\section{Timing of the Offences}

The next stage involves examining whether the time of release from prison has significance for joint participation in crime subsequent to a stay in prison, that 
Table 2. Offence Types Registered for Those Suspected of Committing Offences Together Subsequent to a Joint Stay in Prison

\begin{tabular}{lcc}
\hline Offence type & $n$ & Proportion \\
\hline Crimes against life and health & 1 & 2 \\
Crimes against liberty and peace & 1 & 2 \\
Theft and other crimes of stealing & 17 & 38 \\
$\quad$ (excluding robbery) & 5 & 11 \\
Robbery & 1 & 2 \\
Embezzlement and other breaches of trust & 1 & 2 \\
Criminal damage offences & 3 & 7 \\
Offences against the Weapons Act and the & & \\
$\quad$ Knives Act & 14 & 31 \\
Offences against the Smuggling Act, Drug & & \\
$\quad$ Offences Act & 2 & 5 \\
Burglary & 45 & 100 \\
Total &
\end{tabular}

Note: Proportions in percentage. $n=64$.

is, whether it is common that people who co-offend following a joint stay in prison are released from prison at roughly the same time. To this end, the number of days between the release dates from prison were calculated for the 29 co-offending partnerships who were suspected of committing offences together subsequent to the conclusion of a joint stay in prison. For four of the co-offending partnerships found in the data, the offences took place while both individuals were still serving their prison sentences. These partnerships were thus not relevant in the context of this particular analysis because it focuses on the number of days between the co-offenders' release dates. The analysis shows that the individuals found in this material who were suspected of co-offending subsequent to the conclusion of a joint stay in prison were on average released from prison 20 days apart. ${ }^{8}$

These findings can be interpreted as indicating that being released at roughly the same time is of some significance in relation to the question of future co-offending. It should also be noted in this context that the length of the possible period between the inmates' released dates is limited to a maximum of 182 days, that is, 6 months, which was the period chosen to define the study population. The longest period between the release dates of two individuals who subsequently co-offended lies at 88 days, however, which also suggests that the times of release may be of significance for co-offending. 
Table 3. Type of Prison by Security Classification for Those Suspected of Co-Offending Subsequent to Joint Stay in Prison and for the Study Population as a Whole, Respectively

\begin{tabular}{lcc}
\hline Type of prison & $\begin{array}{c}\text { Suspected of co-offending } \\
\text { subsequent to joint stay in } \\
\text { prison }(n=64)\end{array}$ & $\begin{array}{c}\text { Study population } \\
\text { as a whole } \\
(n=3,930)\end{array}$ \\
\hline $\begin{array}{l}\text { Closed with high } \\
\text { security/closed }\end{array}$ & 3 & 3 \\
Closed & 60 & 38 \\
Closed/open & 28 & 23 \\
Open & 9 & 36 \\
Total & 100 & 100 \\
\hline
\end{tabular}

Note: Proportions in percentage.

The next stage involves examining how many days passed between the co-offending individuals' release dates from prison and the date of their joint offences. Do these offences occur directly subsequent to the co-offenders' release from prison? As the majority of the members of the co-offending partnerships were released on different dates, the analysis is based on the release date of the individual with the latest release date. The results show that a mean of 260 days passed between this release date and the date of the offence.

The members of co-offending partnerships are released on average 20 days apart, whereas the offences they commit together can occur much later. Thus they need not occur directly subsequent to the co-offenders' release from prison. This might be interpreted as indicating that some of the relationships that are established in prison may be of a durable nature, which in turn may effect whether individuals are subsequently suspected of committing offences together, even a relatively long time after they have been released from prison. Previous research on co-offending has not examined the question of timing in this way, which makes interpretations of the above findings more difficult.

\section{Prison Type}

The type of prison in which the 64 individuals spent their prison terms has also been examined. Is it possible that a certain type of prison is likely to promote co-offending more than the others? Table 3 presents the prisons' 
security classes and compares the distribution found within the study population as a whole with that found in the target population.

Most commonly, the 64 individuals were released from closed prisons. It was least common for them to have been released from open prisons. By comparison with the distribution found in the study population as a whole, it is interesting that such a large proportion of these individuals were released from closed prisons ( $60 \%$, as against $38 \%$ of the study population as a whole). One reason for this finding may be that individuals are usually admitted to closed prisons for relatively long periods of time, which may be viewed as being likely to promote the establishment of relationships that may then in turn result in subsequent co-offending. However, it ought to be easier to meet and establish relationships in open than in closed prisons, given the restrictions and security measures in place. Another reason may be that the type of inmates who serve time in closed prisons differ from their counterparts in open prisons, having committed more serious offences and usually having a longer history of involvement in crime, which might conceivable affect future co-offending. Alnæs (2006, p. 129), who studied both an open and a closed prison, found that there were substantial differences between these institutions. At the closed prison, tendencies were noted toward prisonization. As some of the inmates had been admitted to both institutions, it is possible that it is structural factors linked to the type of institution and not the individuals themselves that underlie these tendencies. One view would be that inmates who become prisonized may be more likely to be interested in future co-offending. If this were the case, then it would provide a possible interpretation for the overrepresentation of inmates from closed prisons found among the members of the co-offending partnerships examined in this study.

\section{Discussion}

As institutions, prisons are special in a number of different ways. One of these relates to their function. For the inmates, prisons are among other things intended to serve a rehabilitative function. The work of prisons should focus on measures intended to influence the convicted offender not to reoffend. At the same time, we know that those sentenced to a prison term often do in fact return to crime subsequent to release (Andersson, 1991, p. 72; BRÅ, 2007; Kriminalvårdsstyrelsen, 2005, p. 55-59; Kyvsgaard, 1989, p. 100). In the current study, $73 \%$ of the study population were suspected of new offences within 2.5 years of their release from prison. One possible explanation for this may be that the inmates become prisonized during their time in prison (Alnæs, 
2006, p. 129; Bondeson, 1974, p. 525). This involves them becoming affected by processes of negative influence that serve to intensify their criminal identity and their ties to a criminal subculture. Their interactions with other prison inmates have a negative impact on the likelihood of rehabilitation. It also means that the effects of positive influences, such as contacts with family and noncriminal friends, are weakened. This may be one reason for the high levels of recidivism found among persons sentenced to prison. The structural conditions that lead to prisonization should of course serve to promote the establishment of new contacts for the purposes of future crime. There are other factors, however, that might also have an affect and that may give us insights into why so few inmates are suspected of committing offences together subsequent to spending time in the same prison.

Besides the sanction itself, that is, being locked up, the prison term is governed by various rules. These rules may either be formal, and determined by the regulations of the Prison and Probation Service, or informal, that is, the inmates' own system of rules (Alnæs, 2006, p. 129; Lindberg, 2005, p. 38). The latter include rules relating to how inmates should behave in relation to prison staff and to one another. The inmates should avoid interacting with staff as much as possible. In relation to other inmates, they should be loyal. At the same time, they should distance themselves from inmates who have "grassed," for example, or who are serving time for offences that are not regarded as acceptable. It is important to take care of oneself, not talk, not trust anyone, and not appear weak. Prison society is also characterized by hierarchies among the inmates (Alnæs, 2006, p. 129; Bondeson, 1974, p. 166; Lindberg, 2005, p. 115; Nilsson, 2003). Prior experience of prison, offence type, time served, drug dealing, the inmate's behavior during the prison term and being accepted by other inmates are all factors that affect where inmates will find themselves in such hierarchies. The extent to which an individual is accepted by other inmates is linked to whether the individual in question already knows somebody who is serving time in the prison and/or has a large criminal network. It is possible that the informal rules and an inmate's status in the prison may affect the opportunities available for establishing contacts with other inmates. If this is the case, then only certain inmates will have such opportunities. It is also possible that those who have the opportunity to establish such contacts use it with caution, as it may subsequently turn out that the person they establish a relationship with has not followed the informal prison rules, for example, and that they therefore do not wish to risk being associated with him or her. These factors may contribute insights as to why inmates have varying possibilities for establishing contacts during a stay in prison. 
The cultures found in prisons, which are often labeled subcultures, may differ from one type of prison to another (Alnæs, 2006, p. 126). It is also possible that different types of prison units and variations in the composition of prison inmates could produces different cultures. This study has shown that the individuals who were suspected of co-offending subsequent to a joint stay in prison were usually released from a closed prison. The inmates in prisons of this kind usually have a longer history of criminal involvement, which may affect their level of interest in establishing contacts for the purposes of future co-offending. Although tendencies toward prisonization have been found in closed prisons, such tendencies were not found in open prisons, despite the fact that certain inmates were first admitted to a closed prison and then to a open prison (Alnæs, 2006, p. 130). This finding suggests that structural factors linked to prison type should be taken into consideration to interpret the findings of the current study.

The formal rules that were mentioned above mean that the inmate's time in prison is governed by the regulations of the Prison and Probation Service. This means that there are rules governing when the inmate is to be released from prison. If for example an inmate misbehaves during his or her period of imprisonment, this release date can be delayed, which means that there is a way for inmates to influence when they will be released from prison. For the most part, however, it is fair to say that an inmate's release date is governed by formal rules. The current study has shown that the inmates who were suspected of co-offending subsequent to their release were on average released 20 days apart from one another. This finding suggests that the date of release from prison may be of significance for maintaining contacts and thus for the occurrence of co-offending subsequent to a joint stay in prison. However, the results show that the offences in question are not always committed directly on release. On average, it took 260 days from release before these co-offending partnerships were suspected of their joint offences. In other words, this means that factors that are influenced by the formal rules governing prisons, such as the release date, may be of significance for subsequent co-offending.

It is also possible that various factors associated with the inmates admitted to prisons, that is, individual factors, may affect how contacts are established and whether this leads to subsequent co-offending. As has been mentioned above, the offence for which an inmate is sentenced is of significance for the inmate's status in prison. Certain types of offences are quite simply not regarded as acceptable. In prison, individuals become identified with their actions (Alnæs, 2006, p. 129). The current study shows further that certain offence types, that is, drug offences and robbery, are overrepresented among the offences for which the 36 co-offending partnerships were suspected subsequent to their 
release from prison, by comparison with the distribution of subsequent offending found within the study population as a whole. It is possible that certain inmates seek to expand their networks to include individuals with a certain type of competence. If they meet the right person, it is possible that this may result in co-offending subsequent to their release from prison. As was mentioned earlier, however, the number of offences committed by co-offenders in the current study is small, which means that caution should be exercised when drawing conclusions of this kind.

During their time in prison, inmates will come into contact with other individuals who could be regarded as possible co-offenders. Contacts with other criminals increase the frequency of both reoffending and of offending at the individual level (Nilsson, 2002, p. 142; Sarnecki, 2001, p. 50). The current study shows that those who commit offences together subsequent to a joint period in prison on average have more suspected co-offenders than the study population as a whole. This is true both for the period prior to the current prison term and the period subsequent to release from prison. In other words, it is those individuals who on average have large networks of co-offenders who appear to be interested in further expanding these networks of co-offenders during their time in prison.

Trust has been emphasized as constituting an important factor both among offenders in general and for co-offending to take place (Tremblay, 1993, p. 25; von Lampe \& Johansen, 2003, p. 3). If an individual has a large network of co-offenders, this may provide an indication to others that the individual in question can be trusted (Weerman, 2003, p. 407). A large network may also mean that there is a greater chance of the individual knowing someone in the prison who can serve as a guarantor that he or she is trustworthy (Nilsson, 2003 , p. 47). This would make it easier for the individual in question to be accepted among other inmates and would thus provide better opportunities for establishing new contacts. Prison has also been described as a place where continuous contacts make it possible to study a person's trustworthiness (von Lampe \& Johansen, 2003, p. 3). In other words, it is possible that individuals' trustworthiness can be checked out in various ways over the course of period in prison. This can happen by means of the inmate's prior contacts in the form of networks of co-offenders and through the way the inmate behaves during the prison term.

Individual factors such as sex and age have been examined to see whether they are of significance for co-offending subsequent to a joint stay in prison. It has previously been noted that co-offending usually declines with increasing age (Reiss \& Farrington, 1991, p. 384). In the current study, however, the findings showed that the sex and age distribution among those who were 
suspected of co-offending subsequent to a joint stay in prison were very similar to those found within the study population as a whole. Previous research examining this issue has been based on longitudinal studies, which may explain the discrepancy between the results reported in the current study and the findings reported in previous research. At the same time, it can be noted that it is not sufficient to study only these variables if we are to develop better insights into the phenomenon of co-offending subsequent to a period of imprisonment. To develop a better understanding of this finding, it is possible that other factors, such as the nature of an individual's criminal career for example, may also need to be taken into consideration.

On the basis of the above analysis of both structural and individual factors, we can conclude that there are a large number of factors that must come together for co-offending to occur subsequent to the conclusion of a joint stay in prison. First, the time spent by inmates in prison is governed by a variety of different rules, both formal and informal, which mean that only certain individuals have the opportunities that are necessary to establish contacts. Second, the inmate must be placed in a prison where there exists an interest in establishing contacts for the purposes of future criminality. Third, for co-offending to occur, the inmates in question must be released from prison at approximately the same time. Fourth, an inmate must have knowledge relating to such offences as may be of interest to others if he or she is to become significant as a potential co-offender. Fifth, the inmate him- of herself must be interested in committing offences together with others and in increasing his or her network of co-offenders. Sixth, the inmate must be perceived as an individual who can be trusted on the basis of either observation or the information provided by others. In summary, it may be concluded that many different factors all have a role to play, some of which relate to the opportunities to establish contacts, some to the opportunities to establish contacts during the time spent in prison. This may provide an insight into why so few are suspected of committing offences together subsequent to the conclusion of a joint stay in prison.

To better interpret the results presented above, complementary studies are needed using different types of data. To this end, an interview study has also been conducted (Roxell, 2007) in which questions were asked about contacts in prison, about the significance of these contacts during and subsequent to an inmate's time in prison and about factors that may influence the likelihood of co-offending taking place subsequent to a joint stay in prison. Although the results of this interview study largely support the conclusions drawn in the discussion presented above, the space available unfortunately does not allow for a more detailed presentation of these results in the current article. 


\section{Declaration of Conflicting Interests}

The author(s) declared no potential conflicts of interest with respect to the research, authorship, and/or publication of this article.

\section{Funding}

The author(s) received no financial support for the research, authorship, and/or publication of this article.

\section{Notes}

1. The target population comprised a total of 4,043 individuals. Of these, a complete personal identity number was missing in the cases of 113 individuals, producing a level of missing cases of $2.8 \%$.

2. The Register of Convicted Offenders does not contain data on possible co-offenders. For this reason, the Register of Suspected Offenders is preferable for the purposes of studying issues relating to co-offending.

3. Offences committed during the course of the prison term have been included in the analysis because it is my view that these also reflect relationships established in prison that result in crime. There are no data as to where the offences took place. It is likely, however, that the offences took place either in prison or during periods of prison leave.

4. One day together in prison was chosen as the limit to define a joint stay in prison. I have consciously chosen the lowest possible limit since I feel it is difficult to determine the length of time required to establish contacts that may lead to co-offending.

5. The number of co-offending partnerships is 36 as a result of the fact that one of the 70 individuals has been suspected of committing offences with two different persons.

6. One such finding is that 502 , or $13 \%$, of the individuals in the study population have been suspected of committing offences together with the same individuals (which do not belong to the study population) both prior to and subsequent to their prison term. These individuals together produce a total of 569 co-offending partnerships. Another finding is that 490 , or $13 \%$, of the individuals in the study population, were suspected of committing offences together with an individual who was an inmate in a different prison, or who was an inmate in the same prison as themselves, but at a different time. These individuals comprise a total of 319 co-offending partnerships.

7. Age is calculated for the year 2001, which was the year in which the first members of the study population were released from prison. The median age is 34 , and the standard deviation is 9.86 . 
8. The difference between release dates ranges between 0 and 88 days. The average number of days presented in the text is based on the median. The mean number of days between released dates is 27 , with a standard deviation of 26 . Given the skewed nature of the distribution, the median was chosen as the most suitable measure of central tendency.

9. The findings show that the number of days ranges between 3 and 771 . The median number of days between released date and the time of the offence is 221 , and the standard deviation is 215 .

\section{References}

Alnæs, Ø. (2006). Fengsel-forbryterskole eller rehabiliteringsanstalt. Slik de innsatte opplever det [The prison-crime education or rehabilitation institution. Such inmates are experiencing it.] (Unpublished master's thesis). Kriminalomsorgens utdanningssenter KRUS, Oslo, Norway.

Andersson, J. (1991). Kriminella karriärer och påföljdsval [Criminal careers and choice of sanctions] (Unpublished doctoral dissertation). Department of Sociology, University of Stockholm, Stockholm, Sweden.

Blau, P. M. (1964). Exchange and power in social life. New Brunswick, NJ: Transaction Books.

Blau, P. M. (1994). Structural contexts of opportunities. Chicago, IL: University of Chicago Press.

Bondeson, U. (1974). Fången i fångsamhället. Socialisationsprocesser vid ungdomsvårdsskola, ungdomsfängelse, fängelse och internering [The prisoner in the prison community: Socialization people at school, juvenile detention, imprisonment and detention]. Malmö, Sweden: P. A. Norstedt \& Söners förlag.

BRÅ. (2005). Narkotikabrottslighetens organisationsmönster [Drug crime organization patterns] (Report 2005:11). Stockholm, Sweden: Brottsförebyggande rådet, Fritzes förlag.

BRÅ. (2006). Konsten att läsa statistik om brottslighet [The art of reading statistics on crime]. Retrieved from http://www.bra.se/extra/faq/?module_instance=2\& action=question_show\&id $=349 \&$ category_id $=0$

BRÅ. (2007). Aterfall $i$ brott [Repeat offenses]. Retrieved from http://www.bra.se/ extra/pod/?action $=$ pod_show\&module_instance $=21 \&$ id $=435 \&$ statsType $=840 \& \mathrm{Y}$ ear=2001\&type $=3 \&$ statsPopulation $=$ all

Carlsson, K.-M. (2003). Utvärdering av Västerortspolisens rånkommission [Evaluation of the Stockholm Police Commission]. Stockholm, Sweden: Analysis and statistics office/finance division, Police \& Department of Criminology, University of Stockholm.

Clemmer, D. (1958). The prison community. New York, NY: Holt, Rinehart and Winston. (Original work published 1940) 
Cook, K. (1990). Linking actors and structures: An exchange network perspective. In C. Calhoun, M. W. Meyer, \& R. W. Scott (Eds.), Structures of power and constraint. Papers in honor of Peter M. Blau (pp. 113-128). Cambridge, UK: Cambridge University Press.

Felson, M. (2003). The process of co-offending. In M. J. Smith \& D. B. Cornish (Eds.), Theory for practice in situational crime prevention (Crime Prevention Studies, No. 16, pp. 149-168). New York, NY: Willow Tree Press.

Gendreau, P., Goggin, C., \& Cullen, F. T. (1999). The effect of prison sentences on recidivism (User report 1999-3). Ottawa, Ontario: Solicitor General Canada.

Goffman, E. (1961). Totala institutioner: Fyra essäer om anstaltslivets sociala villkor [Total institutions: Four essays on social conditions of prison life]. Stockholm, Sweden: Rabén \& Sjögren.

Hagan, J., \& McCarthy, B. (1997). Mean streets. Youth crime and homelessness. Cambridge, UK: Cambridge University Press.

Hawkins, G. (1976). The prison: Policy and practice. Chicago, IL: University of Chicago Press.

Hirschi, T. (1969). Causes of delinquency. Berkeley: University of California Press. von Hofer, H. (2006). Svensk våldtäktsstatistik i internationell belysning [Swedish rape statistics in the international setting]. In L. Roxell \& E. Tiby (Eds.), Frågor, fält och filter. Kriminologisk metodbok (pp. 175-190). Lund, Sweden: Studentlitteratur.

Homans, G. C. (1958). Social behavior as exchange. American Journal of Sociology, 63, 597-606.

Justitiedepartementet Dir. (2002). En ny kriminalvårdslag [A new penal law]. Stockholm, Sweden: Department of Justice.

Koons-Witt, B. A., \& Schram, P. J. (2003). The prevalence and nature of violent offending by females. Journal of Criminal Justice, 31, 361-371.

Kriminalvårdsstyrelsen. (2000). Kriminella gängbildningar. En pilotundersökning om gängbildningar vid landets anstalter [Criminal gang formation. A pilot study of gang formation in the country's institutions]. Norrköping, Sweden: Author.

Kriminalvårdsstyrelsen. (2001). Kriminella gängbildningar. Undersökning om gängbildningar vid landets anstalter [Criminal gang formation. Study on gang formation in the country's institutions]. Norrköping, Sweden: Author.

Kriminalvårdsstyrelsen. (2005). Kriminalvårdens redovisning om återfall [Prison service's accounts of relapse]. Norrköping, Sweden: Author.

Kyvsgaard, B. (1989). . . og foengelset ta'r de sista. Om kriminalitet, straf og levevillkår. [.... and the prison take the last ones. About criminality, sentences and life chances]. Copenhagen, Denmark: Jurist- og Økonomforbundets Forlag.

Kyvsgaard, B. (1998). Den kriminelle karriere [The criminal career]. Copenhagen, Denmark: Jurist- og Økonomforbundets Forlag.

von Lampe, K., \& Johansen, P. O. (2003). Criminal networks and trust. Paper presented at the European Society of Criminology Conference in Helsinki, Finland. 
Lindberg, O. (2005). Kvinnorna på Hinseberg. En studie av kvinnors villkor i fängelse [Women at Hinseberg. A study of women's conditions in prison] (Prison Service Research Committee Report Series, Report No. 14). Norrköping, Sweden: Kriminalvården.

McCarthy, B., Hagan, J., \& Cohen, L. E. (1998). Uncertainty, cooperation and crime: Understanding the decision to co-offend. Social Forces, 77(1), 155-176.

Nilsson, A. (2002). Fånge i marginalen. Uppväxtvillkor, levnadsförhållanden och återfall $i$ brott bland fångar [Prisoner in the margin. Growing conditions, living conditions and recidivism among prisoners] (Unpublished doctoral dissertations No. 8). Department of Criminology, University of Stockholm, Stockholm, Sweden.

Nilsson, R. (2003). Hierarkiska förhållanden intagna emellan—en kvalitativ studie om de intagnas inbördes hierarkiska ordning [Hierarchical relationships among inmates: A qualitative study on the prisoners' civil hierarchy] (Finals doctoral dissertation in Sociology). Department of Social Science, Örebro University, Örebro, Sweden.

Pettersson, T. (2002). Tre aspekter på brottsliga nätverk: supporterbråk, etnicitet och genus [Three aspects of the criminal networks: Fan fights, ethnicity, and gender]. (Unpublished doctoral dissertations No. 7). Department of Criminology, University of Stockholm, Stockholm, Sweden.

Pollock, J. M. (2004). Prisons and prison life: Cost and consequences. Los Angeles, CA: Roxbury.

Reiss, A. J., Jr. (1988). Co-offending and criminal careers. In M. Tonry \& N. Morris (Ed.), Crime and justice: An annual review of research (Vol. 10, pp. 117-170). Chicago, IL: University of Chicago Press.

Reiss, A. J., Jr., \& Farrington, D. P. (1991). Advancing knowledge about co-offending: Results from a prospective longitudinal survey of London males. Journal of Criminal Law and Criminology, 82, 360-395.

Roxell, L. (2002). Nätverksanalys av fängelsegäng. En pilotstudie [Network analysis of prison gang: A pilot study] (Prison Service Research Committee Report Series, Report No. 9). Norrköping, Sweden: Kriminalvårdsstyrelsen.

Roxell, L. (2007). Fångar i ett nätverk? Fängelser, interaktioner och medbrottslingsskap [Prisoners in a network? Prisons, interactions and co-offending.] (Unpublished doctoral dissertations No. 24). Department of Criminology, University of Stockholm, Stockholm, Sweden.

Sarnecki, J. (1986). Delinquent networks (The National Council for Crime Prevention, Report No. 17). Stockholm, Sweden: Allmänna Förlaget.

Sarnecki, J. (1999). Ungdomar från särskilda ungdomshem i Stockholms brottsliga nätverk [Young people from special youth in Stockholm criminal networks] (Research Report No 3). Stockholm, Sweden: Statens institutionsstyrelse.

Sarnecki, J. (2001). Delinquent networks youth co-offending in Stockholm. Cambridge, UK: Cambridge University Press. 
Sarnecki, J. (2002). Brottsliga ungdomsnätverk i Köpenhamn [Criminal youth network in Copenhagen]. Unpublished manuscript, Department of Criminology, University of Stockholm, Stockholm, Sweden.

Sarnecki, J. (2004). Girls and boys in delinquent networks. International Annals of Criminology, 42(1/2), 29-52.

Sarnecki, J. (2006). Är rättvisan rättvis? Tio perspektiv på diskriminering av etniska och religiösa minoriteter inom rättsväsendet [Is justice fair? Ten perspectives on discrimination against ethnic and religious minorities in the judiciary] (Report of the Inquiry on power, integration and structural discrimination, SOU 2006:30). Stockholm, Sweden: Fritzes förlag.

Shaw, C. R., \& McKay, H. D. (1942). Juvenile delinquency and urban areas. Chicago, IL: University of Chicago Press.

Sutherland, E. H. (1939). Principles of criminology. Philadelphia, PA: Lippincott.

Sykes, G. M. (1958). The society of captives: A study of a security prison. Princeton, NJ: Princeton University Press.

Tremblay, P. (1993). Searching for suitable co-offenders. In R. V. Clarke \& M. Felson (Ed.), Routine activity and rational choice: Advances in criminological theory (Vol. 5). New Brunswick, NJ: Transaction Publishers.

Tribaut, J. W., \& Kelley, H. H. (1959). The social psychology of groups. New York, NY: John Wiley.

Warr, M. (2002). Companions in crime. The social aspects of criminal conduct. Cambridge, MA: Cambridge University Press.

Weerman, F. M. (2003). Co-offending as social exchange: Explaining characteristics of co-offending. British Journal of Criminology, 43, 398-416.

\section{Bio}

Lena Roxell, $\mathrm{PhD}$, works as a postdoctoral researcher at Stockholm University's Department of Criminology. The article is based on part of her doctoral dissertation, "Fångar i ett nätverk? Fängelser, interaktioner och medbrottslingsskap" [Prisoners in a network? Prisons, interactions and co-offending], which was published in 2007. 